\title{
The Effect of Positive Psychological Capital On Work Engagement
}

\section{Zülbiye Kaçay ${ }^{*}$, Nuri Berk Güngör ${ }^{2}$}

\author{
'Department of Sports Sciences, Çanakkale Onsekiz Mart \\ University, Çanakkale, Turkey \\ ${ }^{2}$ Department of Sports Sciences, Karamanoğlu Mehmetbey \\ University, Karaman, Turkey
}

Study Area: Çanakkale, Turkey

\section{Abstract}

To conclude the study, "Utrecht Work Engagement Scale" the "Positive Psychological Capital Scale" were used as tools. Results indicated that the positive psychological level of the participants was high and their work engagement levels were above the average. Also, it was determined that there was not a statistically significant difference in terms of the participants' psychological capital and work engagement according to the gender variable. Further, it was concluded that self-efficacy and optimism statistically predicted vigour and assimilation; self-efficacy, hope and optimism statistically predicted the concentration. It was determined that $58.4 \%$ of vigour, $36.6 \%$ of assimilation and $48.2 \%$ of concentration were explained by predictorvariables.

abilities at the highest level.

The concept of capital, which in the 1970s was used to emphasize the tangible assets owned, is now referred to different types of capitals such as human, cultural, emotional, and social capital, whose organizational impact is high, but difficult to determine and calculate (Özbek, 2020). Nevertheless, the concept of positive psychological capital has started to come to the fore with the emergence of positive organizational behavior and positive psychological approaches for individuals' attachment to life and bringing life towards positive point (Akdogan \& Polatçi, 2013).

Luthans \& Youssef (2004) mention four types of capital. These are: the economic capital includes physical assets and financial resources you have; human capital, which expresses what you know (experience, education, skills, knowledge, ideas); social capital that refers to relationships, networks, and friends, and psychological capital that defines what kind of a person you are (self-efficacy, hope, optimism, resilience). While competence/trust dimension, which is one of the four dimensions of positive psychological capital, expresses belief in knowledge-skills and abilities to achieve the goal, the hope dimension; refers to researching willpower and alternative ways; the optimism dimension refers to evaluating the positive aspects of events and resilience dimension means the capacity to overcome the problems (Luthans \& Youssef, 2004). Positive psychological capital is about revealing the strengths of the individual and improving them further. In this way, they will be stronger and more productive and will be able to cope with negative emotions more easily (Seligman \& Csikszentmihalyi, 200o). Making decisions and implementing practices that will contribute to the 
development of positive characteristics of physical education teachers, to have positive experiences, and to increase their subjective well-being will increase their psychological capital and increase their sense of belonging and bring their commitment to work to an optimal level.

Commitment to work, expressed in different concepts in the literature (integration with work: Ardiç \& Polatçi, 2009; passion for work: Turgut, 2011; engagement: Özkalp \& Meydan, 2015), is defined by Bezuidenhout \& Cilliers (2010) that employees spend all their energy on their work and fulfill their jobs with high commitment (Bezuidenhout \& Cilliers, 2010). It is also defined as employees passionately working and doing their best to achieve organizational goals (Markos \& Sridevi, 2010). The work engagement is characterized by vigor, which expresses working with a high level of energy, a devotion that emphasizes the importance and enthusiasm of doing work, and concentration, which expresses integration with work (Schaufeli et al., 2002; Balducci et al., 2010). Commitment to work, expressed in different concepts (integration with work: Ardiç \& Polatçi, 2009; passion for work: Turgut, 2011; engagement: Özkalp \& Meydan, 2015), is stated by Bezuidenhout and Cilliers (2010) that employees spend all their energy on their work and commitment. It has been defined as its fulfillment (Bezuidenhout and Cilliers, 2010). It is also defined as employees passionately working and doing their best to achieve organizational goals (Markos \& Sridevi, 2010). Commitment to work is characterized by vigor, which expresses working with a high level of energy, a devotion that emphasizes the importance and enthusiasm of doing work, and concentration, which expresses integration with work (Schaufeli et al., 2002; Balducci et al., 2010). Commitment to work is a concept that expresses focusing only on the work itself (Schaufeli et al., 2006) without being affected by the object, event, situation, possibility, etc. In this respect, dedicated employees are expected to fulfill their responsibilities with high performance and motivation and to be proud of their work. (Shirom, 2010). Considering that physical education and sports teachers exist with their skills and abilities to a great extent, it is expected that they will display this knowledge, skills, abilities, and experiences with passion and great commitment.

Individual characteristics such as self-efficacy, selfesteem, and optimism are among the factors that increase work engagement (Sahinbas, 2018), and therefore, psychological capitals such as self-efficacy, hope, optimism, and psychological resilience are considered to have a positive effect on the level of commitment of physical education and sports teachers. For this reason, it can be stated that determining the effect of psychological capital on employees' commitment to work will contribute to the determination of the obstacles in performing their jobs with the best performance. From this point of view, the aim of the study was to investigate whether the positive psychological capital levels of physical education and sports teachers had an effect on their level of work engagements.

\section{Materials and Methods:}

The relational screening model was used in this study, in which the effect of physical education and sports teachers' positive psychological capital on their work engagement was examined. Relational screening models are research models that aim to determine the presenceand/or degree of co-change between two or more variables (Karasar, 2013).

The study group of the research comprised of 93 (29.7\%) female and $220(70.3 \%)$ male participants who work as physical education and sports teachers in state schools in the 2019-2020 academic year. Since there were no missing or errors in the data obtained within the scope of the research, all of the data were used. Besides, the easy sampling method was used among purposeful sampling methods. The average age of the participants participating in the research was determined as 41.13.5 \pm 7.85 (18-6o age).

In the research in addition to the personal information form, Positive Psychological Capital (PPC) and Work Engagement Scales (WES) were used. PPC scale developed by Luthans et al., (2007) and adapted to Turkish by Erkmen \& Esen (2013) consists of 18 items and 3 sub-dimensions. Sub dimensions had been named self-efficacy, hope, and optimism. The scale is a 5 point Likert type. When the original form of the scale was examined; Internal consistency coefficients were expressed as $.89, .88, .81$ respectively for the sub-dimensions, and .88 for the whole. The internal consistency coefficients obtained from the data set are .94 for the whole scale; for the sub-dimensions, it is .90, .86, and .81, respectively. Within the scope of the research, the "Utrecht Work Engagement Scale" (WES) developed by Schaufeli \& Bakker (2003) was used. The scale has a 7-point Likert structure and consists of 3 subdimensions. The names of the sub-dimensions are vigor, assimilation, and concentration. It can be stated that the higher the score obtained from the scale, the higher the level of work engagement. The internal consistency coefficients obtained from the data set are .93 for the whole scale; For sub-dimensions, it was determined as .90, .83, and .85 , respectively.

In the process of analyzing the research data, firstly, the significant result of the Shapiro-Wilk test was examined and the skewness and kurtosis values were taken into account in order to determine whether the data set was normally distributed. These values for the measurement tools used in the study are between -1.5 and +1.5 . These values show that the data are distributed normally (Tabachnick \& Fidell, 2013). Normality and linearity assumptions were examined to determine whether the data set was suitable for regression analysis. A linear relationship was determined in the resulting scatter diagram. With this 
result, it can be said that the data set provides the assumptions of multiple linear regression analysis. Pearson Product Moment Correlation Coefficient ( $r$ ) was used to determine the relationship between variables in the study. Multiple linear regression analysis was performed between the variables of positive psychological capital and work engagement. In addition, the mean scores obtained from the scales were described using descriptive statistics. In addition, the T-test and One Way ANOVA tests were also used. The analyzes used in the research were carried out through the SPSS 22 Package Program and Excel Database.

\section{Results:}

All the tables are self-explanatory.

Table-1: Average Scores of the Participants obtained from the Positive Psychological Capital Scale ( $\mathrm{n=313)}$

\begin{tabular}{lllll}
\hline Scales & Min. & Max. & $\overline{\mathrm{x}}$ & $\mathrm{S}$ \\
\hline Self-EfficacySub-Dimension & 2.11 & 5.00 & 4.34 & .50 \\
HopeSub-Dimension & 2.14 & 5.00 & 4.28 & .52 \\
Optimism Sub-Dimension & 1.50 & 5.00 & 4.06 & .78 \\
Positive Psychological Capital & 2.33 & 5.00 & 4.29 & .48
\end{tabular}

Table-2: Average Scores of the Participants obtained from the Work Engagement Scale $(\mathrm{n}=313)$

\begin{tabular}{lllll}
\hline Scales & Min. & Max. & $\overline{\mathrm{x}}$ & $\mathrm{S}$ \\
\hline VigorSub-Dimension & 3.00 & 7.00 & 5.77 & .94 \\
DedicationSub-Dimension & 3.00 & 7.00 & 5.93 & .79 \\
AbsorbtionSub-Dimension & 1.00 & 7.00 & 5.46 & 1.06 \\
Work Engagement Scale & 3.24 & 7.00 & 5.71 & .82 \\
\hline
\end{tabular}

Table-3: T-Test Results of the Average Score Obtained from Positive Psychological Capital and Work Engagement Scales According to the Gender Variable

\begin{tabular}{llllllll}
\hline Scales & Gender & $\mathrm{N}$ & $\overline{\mathrm{x}}$ & $\mathrm{S}$ & $\mathrm{sd}$ & $\mathrm{T}$ & $\mathrm{P}$ \\
\hline PsyCap. & Female & 93 & 4.25 & .48 & 311 & -.85 & .39 \\
& Male & $\mathbf{2 2 0}$ & $\mathbf{4 . 3 0}$ & .49 & & & \\
Work Engagement & Female & 93 & 5.61 & .88 & 311 & -.16 & .86 \\
& Male & $\mathbf{2 2 0}$ & 5.75 & .79 & & & \\
& Total & \multicolumn{2}{c}{313} & & & & \\
\hline
\end{tabular}

Table-4: One-Way ANOVA Results of Average Scores Obtained from Positive Psychological Capital and Work Engagement Scales According to the Tenure Variable

\begin{tabular}{|c|c|c|c|c|c|c|}
\hline Scale & Tenure & $\mathrm{N}$ & $X$ & SS & $\mathrm{F}$ & $\mathrm{P}$ \\
\hline & 1-5 Years & 44 & 4.17 & 0.47 & \multirow{2}{*}{\multicolumn{2}{|c|}{$\begin{array}{ll}4.78 & .001\end{array}$}} \\
\hline & 6-10 Years & 65 & 4.29 & 0.48 & & \\
\hline & \multirow{2}{*}{$\begin{array}{l}\text { 11-15 Years } \\
\text { 16-20 Years }\end{array}$} & 37 & 4.13 & 0.56 & \multirow{4}{*}{\multicolumn{2}{|c|}{$\begin{array}{l}\text { Sig. Diff. =Between } \\
\text { the years } 1-5,11-15 \text {, } \\
16-20 \text { and } \geq 21 \text { in } \\
\text { favor of } \geq 21\end{array}$}} \\
\hline & & 51 & 4.17 & 0.43 & & \\
\hline & $\geq 21$ & 116 & 4.43 & 0.46 & & \\
\hline & Total & 313 & 4.29 & 0.48 & & \\
\hline & 1-5 Years & 44 & 5.55 & 0.73 & $5 \cdot 33$ & .000 \\
\hline & 6-10 Years & 65 & 5.68 & 0.79 & & \\
\hline & 11-15 Years & 37 & $5 \cdot 39$ & 0.87 & Sig. & iff.= Between \\
\hline & 16-20 Years & 51 & $5 \cdot 54$ & 0.76 & thes & $\begin{array}{l}\text { ers } 1-5,11-15 \\
\text { and } 21 \text { and }\end{array}$ \\
\hline & $\geq 21$ & 116 & $5 \cdot 96$ & 0.82 & over & favor of 21 \\
\hline & Total & 313 & $5 \cdot 71$ & 0.82 & and & \\
\hline
\end{tabular}

Considering the analysis results, it was concluded that the participants' commitment to work did'nt differ as per the gender (Table-3).

A statistically significant difference between the Average Scores obtained from the Positive Psychological Capital and Work Engagement Scales, and the tenure (ANOVA). The Tukey analysis results applied in order to determine between which groups the detected difference was; 1-5, 11-15, 16-20 and 21 and above revealed a difference in favour of 21 and above (Table-4).

Table-5: Investigation of the Relationship Between Variables

Using the Pearson Product Moment Correlation $(\mathrm{p}<. \mathrm{o} 1)$

\begin{tabular}{lllllll}
\hline & $\mathrm{SE}$ & $\mathrm{H}$ & $\mathrm{O}$ & $\mathrm{V}$ & $\mathrm{AS}$ & $\mathrm{CO}$ \\
\hline $\mathrm{SE}$ & 1 & & & & & \\
$\mathrm{H}$ & $.81^{* *}$ & 1 & & & & \\
$\mathrm{O}$ & $.55^{* *}$ & $.58^{* *}$ & 1 & & & \\
$\mathrm{~V}$ & $.69^{* *}$ & $.65^{* *}$ & $.64^{* *}$ & 1 & & \\
$\mathrm{AS}$ & $.57^{* *}$ & $.52^{* *}$ & $.47^{* *}$ & $.63^{* *}$ & 1 & \\
$\mathrm{CO}$ & $.63^{* *}$ & $.62^{* *}$ & $.56^{* *}$ & $.65^{* *}$ & $.62^{* *}$ & 1 \\
\hline
\end{tabular}

A positive and moderate relationship was determined between "self-efficacy (SE)" and "vigor (V)", "assimilation (AS)" and "concentration (CO)". A positive and moderate relationship was determined between "hope $(\mathrm{H})$ " and "vigor (V)", "assimilation (AS)" and "concentration (CO)". On the other hand, it is seen that there is a positive and moderate relationship between "optimism (O)" and "vigor (V)", "assimilation (AS)" and "concentration (CO)".

Table-6: Results of Multiple Regression Analysis Regarding Predicting Work Engagement

\begin{tabular}{lllllll}
\hline Variables & Std. $\beta$ & \multicolumn{3}{l}{ St. Error Critical Rate } & $p$ & R2 \\
\hline Vigor & .41 & .12 & 6.41 & .00 & .58 & \\
& .11 & .11 & 1.71 & .09 & & \\
Absorbtion & .34 & .05 & 7.58 & .00 & & \\
& .39 & .13 & 4.98 & .00 & .36 & \\
& .08 & .12 & .98 & .33 & & \\
Concentration & .20 & .05 & 3.64 & .00 & & \\
& .33 & .15 & 4.65 & .00 & .48 & \\
& .19 & .15 & 2.62 & .01 & & \\
& .26 & .07 & 5.19 & .00 & & \\
\hline
\end{tabular}

\section{Discussion and Conclusion:}

Positive psychological capital and work engagement are the concepts included in organizational behavior and have become a subject of study in the last few years (Ciftci \& Erkanli, 2020). In this study, it was aimed to determine whether the positive psychology capital levels of physical education and sports teachers which shown a significant effect on the level of work engagement and whether gender and tenure have a significant effect on these variables.

Considering the participants' average scores obtained from the Positive Psychological Capital Scale and subdimensions, it can be said that the positive psychological capital levels of the participants were high (Table-1). According to the mean scores obtained from the Work Engagement Scale and its sub-dimensions and 
concentration (Table 2), it can be stated that the level of work engagement of the participants was above the average. Accordingly, it can be said that the participants were aware of their knowledge, skills, and abilities, and their beliefs that they can achieve it by finding positive aspects with a positive perspective even in challenging tasks, by trying alternative ways and keeping their motivation high. When considered from this point of view, it can be stated that keeping the positive psychological capital levels of physical education and sports teachers high will contribute to the organization in terms of performance, efficiency and increasing productivity, job satisfaction, adapting to change easily, and overcoming problems. Some of the studies have parallel results of our study (Tösten \& Özgan, 2017; Li \& He, 2011; Keser, 2013). On the other hand, the high level of work engagement of the employees is important in terms of being able to do things with enthusiasm and high motivation. In terms of its contribution to the organization, it may be possible to achieve saving with the correct and appropriate use of time, energy, and attention.

When Table- 3 was examined; It was determined that gender variable had no effect on the participants' positive psychological capital and work engagement levels. Parallel to this result; Köse (2016) found that gender does not have a significant effect on teachers' level of engagement. Bostanci \& Ekiyor (2015) found that there was no significant difference between a commitment to work and gender. Yalçin's (2019) examined the Positive Psychological Capital Levels of Teachers and concluded that the positive psychological capital levels of teachers did not show a significant difference in the dimensions of "hope", " resilience", "optimism" according to their gender. Unlike this study, Ugwu (2013) found that there is a significant relationship between work engagement and gender. Also, Arslan \& Demir (2017) found in their study on judges and nurses that gender had a significant effect on job dedication and job satisfaction, and men were more engaged in jobs. This difference is thought to result from the sample group.

According to the service period/tenure (Table-4); a statistically significant difference was determined between the average points obtained from the Positive Psychological Capital and Work Engagement Scales and tenure. It was determined that this difference was in favor of 21 and over between the years 1-5, 11-15, 16-20, and $\geq 21$. Köse (2016), Tösten \& Özgan (2017) support this finding .

When Table-5 regarding the relationships between variables was examined; A positive and moderate relationship was determined between "self-efficacy (SE)" and "vigor (V)", "assimilation (A)" and "concentration (CO)". A positive and moderate relationship was determined between "hope (H)" and "vigor (V)", "absorption (AB)" and "concentration (CO)". On the other hand, it was observed that there was a positive and moderate relationship between "optimism (O)" and "vigor (V)", "assimilation (AS)" and "concentration (CO)". As per this result, it can be stated that there was a positive, significant relationship at medium and high levels between all subdimensions of the two scales. In other words, as the positive capital levels increase, the levels of work engagement increase. The positive psychological capital has a positive relationship with organizational commitment (Çetin, 2011; Kim, 2015), organizational trust (Shukla \& Rai, 2015), organizational citizenship behavior (Jung \& Yoon, 2015), etc were already reported. Besides, Ouweneel et al., (2012) concluded that there is a positive relationship between the hope levels of employees and their level of engagement. Simons \& Buitendach (2013) found a positive relationship between call center employees' psychological capital, organizational commitment, and engagement. Chaurasia \& Shukla (2014) revealed in their studies that psychological capital has a mediating role in increasing job performance. Çelik et al., (2018) found that as the engagement level of the participants increased, the effect of their psychological capital levels on their professionalism became stronger. Waal \& Pienaar (2013), Paek et al. (2015), Chen (2015), Joo et al. (2015), Simons \& Buitendach (2013), Kaya (2016). The works of Ciftci \& Erkanli, (2020) also support the positive relations between psychological capital and engagement.

Analysis results (Table-6) show that there is a statistically significant effect on the relationship of selfefficacy and optimism with vigor. It was determined that self-efficacy and optimism significantly affected assimilation. This result can be interpreted as the belief of employees in what they can do, identification with their job, and positive evaluations that can contribute to doing their job energetically and with full motivation. It was concluded that hope variable did not have a significant effect on vigor. However, it can be stated that there is no significant effect between hope and assimilation. Also; a statistically significant effect was found in the relationship of selfefficacy, hope, and optimism with concentration. When the values of the model wre examined.

\section{References:}

Agirman, Ü.H.Ç. \& Naktiyok, A. (2018): Psikolojik sermaye ve profesyonellik iliGkisinde iGe angaje olmanin düzenleyici rolü. Atatürk Üniversitesi Sosyal Bilimler Enstitüsü Dergisi, 22(3):2665-2683.

Akdogan, A. \& Polatçi, S. (2013): Psikolojik sermayenin performans üzerindeki etkisinde is-aile yayilimi ve psikolojik iyi olusun etkisi. Atatürk Üniversitesi Sosyal Bilimler Enstitüsü Dergisi, 17(1):273-293.

Ardiç, K. \& Polatçi, S. (2009): Tükenmislik Sendromu ve Madalyonun Öbür Yüzü: Isle Bütünlesme. Erciyes Üniversitesi IIBF Dergisi, 32.

Arslan, E.T. \& Demir, H. (2017): Ise Angaje Olma ve Is Tatmini Arasindaki Iliski: Hekim Ve Hemsireler Üzerine Nicel Bir Arastirma. Yönetim ve Ekonomi, 24(2):371-389.

Balducci, C., Fraccaroli, F. \& Schaufeli, W.B. (2010): Psychometric Properties of the Italian Version of the Utrecht Work 
Engagement Scale(UWES-9): A Cross-Cultural Analysis. $\underline{E u}$. J. Psychol.Asses., 26(2):143-149.

Bezuidenhout, A. \& Cilliers, F.V.N. (2010): Burnout, work engagement and sense of coherence in female academics in higher-education institutions in South Africa. SA J. Indus. Psychol., 36(1):1-10.

Bostanci, H. \& Ekiyor, A. (2015): Calisanlarin ise adanmasinin orgut ici girisimcilige etkisinin incelenmesi: saglik sektorunde bir uygulama. Int. J. Healt. Manag. Strat. Res., 1(1):37-51.

Chaurasia, S. \& Shukla, A. (2014): Psychological capital, lmx, employee engagement \& work role performance. In. J. Industr. Relat, 50(2):342-356.

Chen, S.L. (2015): The relationship of leader psychological capital and follower psychological capital, job engagement and job performance: a multilevel mediating perspective. Int. I. Human Resource Manag., 26(18):2349-2365.

Ciftci, D.O. \& Erkanli, H. (2020): Mediating role of the positive psychological capital on the relation between the authentic leadership style and employees' work engagement: an applied study on hospitality industry. Busi. Econ. Res. J., 11(2):461-478.

Erkmen, T. \& Esen, E. (2013): Psikolojik Sermaye Ölçeginin Geçerlilikve Güvenilirlik Çalismasi. Öneri, 10:23-30.

Joo B.K., Lim, D.H. \& Kim, S. (2015): Enhancing work engagement: The roles of psychological capital, authentic leadership, and work empowerment. Leader. Org.. Develop. J., 37(8):1117-1134.

Kaçay, Z. \& Soyer, F., (2020): Is Yeri Yilmazliginin Yordayicilari Örgütsel Güven, Lider-Üye Etkilesimi ve Is Yeri Maneviyati. Pub. by: LAP LAMBERT Academic Publishing.

Karasar, N. (2013): Bilimsel Arastirma Yöntemi, (25. Baski). Pub. by: Nobel Yayincilik, Ankara.

Kaya, E. (2016): Is Talepleri ve Is Kaynaklarinin Ise Tutkunluga Etkisinde Pozitif Psikolojik Sermayenin Aracilik Rolünün Incelenmesi. (Yayinlanmamis Yüksek Lisans Tezi), Istanbul: Maltepe Üniversitesi Sosyal Bilimler Enstitüsü.

Keser, S. (2013): Ilkögretim Okulu Yöneticilerinin Otantik Liderlik Ve Psikolojik Sermaye Özelliklerinin Karsilastirilmasi. Yayimlanmamis Yüksek lisans Tezi. Yildiz Teknik Üniversitesi Sosyal Bilimler Enstitüsü Egitim Yönetimi Teftis Planlama Ekonomisi Anabilim Dali.

Köse, A. (2016): Ögretmenlerin iseangaje olmalarinda demografik özelliklerinin rolü. Turk. J. Edu., 5(4):255-264.

Li, L. \& He, X. (2011): The Researches on Positive Psychological Capital and Coping Style of Female University Graduates in the Course of Seeking Jobs.

Luthans, F. \& Jensen, S. (2009): Psychological capital: A positive resource for combating employee stress and turnover. Human Resource Management, :677-693.

Luthans, F. \& Youssef, C.M. (2004): Human, social, and now positive psychological capital management: Investing in people for competitive advantage. Org. Dyn. 33(2):143-160.

Luthans, F., Bruce, J., Avolio, J.B., Avey, \& Steven M.N. (2007): Positive psychological capital: measurement and relationship with performance and satisfaction. Pers. Psychol., 6o(3):541-572.

Markos, S. \& Sridevi, M.S. (2010): Employee engagement: The key to improving performance. Int. J. Bus. Manag. $5(12): 89-96$.

Ouweneel, E., Le Blanc, P.M., Schaufeli, W.B. \& Ivan Wijhe, C.
(2012): Good morning, good day: A diary study on positive emotions, hope, and work engagement. Human Relat., 65(9):1129-1154.

Özbek, T.D. (2020): Psikolojik Sermayenin Örgütsel Stresle Basa Çikma Ve Örgütsel Baglilikla Iliskisi: Hayvanat Bahçesi Çalisanlari Üzerine Bir Arastirma. Yüksek Lisans Tezi. Bahçesehir Üniversitesi Sosyal Bilimler Enstitüsü, Insan Kaynaklari Yüksek Lisans Programi.

Özkalp, E. \& Meydan, B. (2015): Schaufeli Ve Bakker Tarafindan Gelistirilmis Olan Ise Angaje Olma Ölçeginin Türkçede Güvenilirlik Ve Geçerliliginin Analizi. Is,Güç Endüstri Iliskilerive Insan Kaynaklari Dergisi, 17(3):4-19.

Paek, S., Schuckert, M., Kim, T.T. \& Lee, G. (2015): Why is hospitality employees' psychological capital important? The effects of psychological capital on work engagement and employee morale. Int.J. Hospit. Manag.. 50:9-26.

Sahinbas, F. (2018): Pozitif Örgütsel Davranis Yaklasimiyla Isyeri Arkadasligi Ve Ise Adanma Iliskisi: Saglik Çalisanlari Üzerine Bir Arastirma. Yüksek Lisans Tezi. Hacettepe Üniversitesi Sosyal Bilimler Enstitüsü Saglik Yönetimi Anabilim Dali.

Schaufeli, W.B. \& Bakker, A.B. (2003): Utrecht work engagement scale: Preliminary manual. Pub. by: Occupational Health Psychology Unit, Utrecht University, Utrecht.

Schaufeli, W.B., Salanova, M., González-Romá, V. \& Bakker, A.B. (2002): The measurement of engagement and burnout: A two sample confirmatory factor analytic approach. L. Happi. Stud., $3(1): 71-92$.

Schaufeli, W.B., Bakker, A.B. \& Salanova, M. (2006): The measurement of work engagement with a short questionnaire. Edu. Psychol. Measure., 66:701-716.

Shirom, A. (2010): Feeling energetic at work: On Vigor's Antecedents, Work Engagement: A Handbook of Essential Theory and Research. Pub. by: Psychology Press, New York, 2010.

Simons, J.C. \& Buitendach, J.H. (2013): Psychological capital, work engagement and organisational commitment amongst call centre employees in South Africa. South Africa. SA Tydskrif vir Bedryfsielkunde, 39(2):12.

Simons, J.C. \& Buitendach, J.H. (2013): Psychological capital, work engagement and organisational commitment amongst call centreemployees in South Africa. South Africa.

Tabachnick, B.G. \& Fidell, L.S. (2013): Using multivariate statistics (6th ed.), Pub. by: Allyn and Bacon, Boston.

Turgut, T. (2010): “Çalismaya Tutkunluk” (Ed. Güler Islamoglu), , Baski, Nobel Yayincilik , Ankara.Ugwu, F.O. (2013): Work engagement in Nigeria: Adaptation of the utrecht work engagement scale for Nigerian samples. Int. J. Multidisc. Acad. Res., 1(3):16-26.

Uysal, B., Özçelik, G. \& Uyargil, C.B. (2018): Bireysel is yapilandirmanin sonuçlari: Bireysel is yapilandirmanin psikolojik sermaye ve ise adanmislik üzerindeki etkisinin degerlendirilmesi. Yönetim Bilimleri Dergisi, 16(32):651-666.

Waal, J.J. \& Pienaar, J. (2013): Towards understanding causality between work engagement and psychological capital. $\underline{S A}$. J. Indust. Psychol., 39(2):1-10.

Yalçin, S. (2019): Ögretmenlerin Pozitif Psikolojik Sermaye Düzeylerinin Incelenmesi. Anadolu Üniversitesi Sosyal Bilimler Dergisi, 19(1):13-26. 